\title{
Cinnamomum camphora var. linaloolifera essential oil on pest control: Its effect on
}

\section{Trialeurodes vaporariorum (Hemiptera: Aleyrodidae)}

\author{
Óleo essencial de Cinnamomum camphora var. linaloolifera no controle de pragas: Seu efeito sobre \\ Trialeurodes vaporariorum (Hemiptera: Aleyrodidae)
}

Aceite esencial de Cinnamomum camphora var. linaloolifera en el control de plagas: Su efecto sobre

Trialeurodes vaporariorum (Hemiptera: Aleyrodidae)

Received: 05/17/2021 | Reviewed: 05/27/2021 | Accept: 06/16/2021 | Published: 06/29/2021

\author{
Camila Bonatto Vicenço \\ ORCID: https://orcid.org/0000-0003-0713-7707 \\ University of Caxias do Sul, Brazil \\ E-mail: cbvicenc@ucs.br \\ Wendel Paulo Silvestre \\ ORCID: https://orcid.org/0000-0002-9376-6405 \\ University of Caxias do Sul, Brazil \\ E-mail: wpsilvestre@ucs.br \\ Gabriel Fernandes Pauletti \\ ORCID: https://orcid.org/0000-0001-9850-3682 \\ University of Caxias do Sul, Brazil \\ E-mail: gfpaulet@ucs.br \\ Neiva Monteiro de Barros \\ ORCID: https://orcid.org/0000-0002-6748-3428 \\ University of Caxias do Sul, Brazil \\ E-mail:nmbarros@ucs.br \\ Joséli Schwambach \\ ORCID: https://orcid.org/0000-0001-6785-4164 \\ University of Caxias do Sul, Brazil \\ E-mail: jschwambach@ucs.br
}

\begin{abstract}
This study evaluated the insecticidal effect of Cinnamomum camphora var. linaloolifera essential oil and its major compound, linalool, on Trialeurodes vaporariorum. Essential oil treatments were applied at $0.5,1.0,1.5$, and $2.0 \% \mathrm{v} / \mathrm{v}$ on eggs, nymphs, and adult individuals and linalool equivalent concentrations on nymphs of T. vaporariorum. The negative controls water and Tween $-80^{\circledR}(0.5 \% \mathrm{v} / \mathrm{v})$ and a positive control (spiromesifen $0.05 \% \mathrm{v} / \mathrm{v}$ for eggs and nymphs; pymetrozine $0.04 \% \mathrm{~m} / \mathrm{v}$ for adults) were also used. The essential oil of $C$. camphora at $2.0 \% \mathrm{v} / \mathrm{v}$ caused egg mortality of $49.7 \%$; same concentration caused the highest nymph mortality $(88.5 \%)$. For adults, the essential oil at $2.0 \% \mathrm{v} / \mathrm{v}$ caused the highest mortality (40.0\%) after $48 \mathrm{~h}$, not changing from 48 to $72 \mathrm{~h}$. The essential oil and linalool performed similarly relative to the nymphs, whose mortalities have not differed statistically, with exception of the concentrations of 0.5 and $1.0 \% \mathrm{v} / \mathrm{v}$. Regarding the chemical control, the concentration of $2.0 \% \mathrm{v} / \mathrm{v}$ has had similar mortality for nymphs; for eggs and adults, the essential oil caused lower mortality (49.4 and 40.0\%) than the synthetic pesticide (65.0 and $72.0 \%$ ). The essential oil of $C$. camphora may be a potential control alternative for $T$. vaporariorum, especially regarding the Integrated Pest Management (IPM) practices.
\end{abstract}

Keywords: Alternative control; Greenhouse whitefly; Linalool; Terpenes; Bioinsecticide.

\section{Resumo}

Este trabalho avaliou o efeito inseticida do óleo essencial de Cinnamomum camphora var. linaloolifera e seu compostos majoritário, o linalol, sobre Trialeurodes vaporariorum. Tratamentos contendo óleo essencial nas concentrações de 0,5; 1,$0 ; 1,5$ e 2,0\% v/v foram aplicados sobre ovos, ninfas e indivíduos adultos de T. vaporariorum. Os controles negativos foram água e Tween- $80^{\circledR}(0,5 \% \mathrm{v} / \mathrm{v})$ mais um controle positivo (espiromesifeno 0,05\% v/v para ovos e ninfas; pimetrozina $0,04 \% \mathrm{~m} / \mathrm{v}$ para adultos) foram também usados. O óleo essencial de C. camphora a 2,0\% v/v causou mortalidade de ovos de 49,7\%; a mesma concentração causou a maior mortalidade de ninfas (88,5\%). Para os adultos, o óleo essencial a 2,0\% v/v causou a maior porcentagem de mortalidade (40,0\%) após 48 h, não se alterando entre 48 e 72 h. O óleo essencial e o linalol tiveram desempenho semelhante com relação às ninfas, cujas mortalidades não diferiram estatisticamente, com exceção das concentrações de 0,5 e 1,0\% v/v. Em relação ao controle químico, a concentração de $2,0 \%$ v/v apresentou mortalidade similar para ninfas; para ovos e adultos, o óleo essencial causou menores mortalidades $(49,4$ e $40,0 \%)$ do que o pesticida sintético $(65,0$ e 72,0\%). O óleo essencial de C. camphora 
pode ser uma alternativa de controle para T. vaporariorum, especialmente tendo em vista as práticas do Manejo Integrado de Pragas (MIP).

Palavras-chave: Controle alternativo; Mosca-branca-de-casa-de-vegetação; Linalol; Terpenos; Bioinseticida.

\section{Resumen}

Este trabajo evaluó el efecto insecticida del aceite esencial de Cinnamomum camphora var. linaloolifera y su compuesto principal, linalool, en Trialeurodes vaporariorum. Tratamientos que contienen aceite esencial en concentraciones de 0,5; 1,0; Se aplicaron 1,5 y 2,0\% v/v a huevos, ninfas e individuos adultos de T. vaporariorum. Los controles negativos fueron agua y también se utilizó Tween-80® (0,5\% v/v) más un control positivo (espiromesifeno $0,05 \%$ v/v para huevos y ninfas; pimetrozina $0,04 \%$ p/v para adultos). El aceite esencial de $C$. camphora al 2,0\% v/v provocó una mortalidad de huevos del 49,7\%; la misma concentración causó la mayor mortalidad de ninfas (88,5\%). Para los adultos, el aceite esencial al $2.0 \%$ v/v causó el mayor porcentaje de mortalidad (40,0\%) después de 48 h, y no cambió entre 48 y 72 h. El aceite esencial y el linalol se comportaron de manera similar en relación a las ninfas, cuyas mortalidades no difirieron estadísticamente, con la excepción de concentraciones de 0,5 y 1,0\% v/v. En relación al control químico, la concentración de 2,0\% v/v presentó similar mortalidad para ninfas; para huevos y adultos, el aceite esencial causó una menor mortalidad (49,4 y 40,0\%) que el plaguicida sintético (65,0 y 72,0\%). El aceite esencial de C. camphora puede ser un control alternativo para $T$. vaporariorum, especialmente considerando las prácticas de Manejo Integrado de Plagas (MIP).

Palabras clave: Control alternativo; Mosca blanca de invernadero; Linalol; Terpenos; Bioinsecticida.

\section{Introduction}

Trialeurodes vaporariorum (Westwood, 1856) is considered the main pest in ornamental and vegetables in protected cultivations (Lourenção et al., 2008). More than 250 species of plants are susceptible to this insect (Zapata et al., 2016), whose attacks cause economic losses to the agricultural sector (CABI, 2017).

T. vaporariorum feeds on sap (phloem) by introducing its buccal apparatus in plant leaves, causing mechanical damage to the plant tissues. The damage is characterized by localized spots and yellowing and fall of leaves; if the infestation reaches critical levels, wilting and reduction of the growth of the host plants may also be seen (Capinera, 2008).

Most of the phloem ingested is not metabolized by T. vaporariorum, being excreted as honeydew, a sugary substance rich in carbohydrates (Henneberry et al., 1999). The honeydew covers fruits and leaves and serves as food to a saprophyte fungus, rendering the plant surface blackish and sticky (Perring et al. 2018). This indirect damage fosters the development of a fungus (Capnodium sp.), which harms the leaves' physiological processes, causing them to wilt and fall, hastening the development cycle of the cultivation (Barbosa et al., 2002). T. vaporariorum may also act as a vector in transmitting viral diseases, which causes severe damage and production loss in several kinds of vegetables (Capinera, 2008).

This insect's management is carried out mainly by using synthetic pesticides (Michereff Filho \& Inoue-Nagata, 2015). In general, large-spectrum pesticides are used without considering the negative impacts that come from the excessive use of chemical control because, in many cases, several applications are necessary, which results in excessive use of synthetic molecules. Hence, pesticide-resistant individuals of T. vaporariorum are continuously selected (Erdogan et al., 2012; Ovčarenko et al., 2014).

The integration of several control techniques may be useful in the reduction of $T$. vaporariorum infestations. Natural products, such as plant extracts and essential oils, may be used as tools to help control this pest. Essential oils could be considered as large-spectrum pesticides (have several modes of action) and low risk (due to the quick volatilization and limited field permanence) (Koul et al., 2008). Unlike synthetic pesticides, essential oils may act by several mechanisms, reducing the probability of the individuals becoming resistant due to the diverse composition of active compounds in essential oils (Pavela \& Benelli, 2016).

Essential oils are complex mixtures of naturally occurring compounds, which are secondary metabolites of plant metabolism and may contain more than 300 compounds at different concentrations (Sell, 2006). Several factors determine the chemical composition of essential oils, both biotic and abiotic (luminosity, water stress, attack by pests and pathogens), which 
may be correlated (Morais, 2009; Pandey et al., 2014; Campos et al., 2019; Silvestre et al., 2019).

Many essential oils obtained from plants of several botanical families show some insecticidal activity or repellent on arthropods. In general, essential oils may be absorbed by the cuticle, inhaled, or ingested by the insects (Regnault-Roger \& Hamraoui, 1995). Inside the several families, the genus Cinnamomum highlights itself, which is already cited in the literature as presenting biological activity (Nerio et al., 2010).

The Cinnamomum genus, belonging to the Lauraceae family, is constituted by approximately 330 species; many produce essential oils. The essential oil of Cinnamomum camphora Ness and Eberm var. linaloolifera Fujita, commonly known as 'ho-sho', is cited in the literature as having antimicrobial, antioxidant, and insecticidal activities (Liu et al., 2006; Cansian et al., 2010; Gilles et al., 2010; Wang et al., 2011; Tomazoni et al., 2017).

The chemical composition of $C$. camphora essential oil is already presented and discussed in the literature; its major compound, linalool, is a monoterpene whose repellent and insecticidal properties were addressed by other researchers, suggesting the potential use to control T. vaporariorum (Cansian et al., 2010, 2015; Tambwe et al., 2014).

This work aimed to evaluate the chemical composition of the essential oil of C. camphora var. linaloolifera and investigate the effect of the essential oils on eggs, nymphs, and adults of $T$. vaporariorum, also evaluating the activity of linalool on nymphs of this pest, aiming to get an alternative form of control for this insect.

\section{Methodology}

The experiments and the evaluation of the insecticidal activity of the C. camphora essential oil on T. vaporariorum were carried out in the Laboratory of Pest Management of the University of Caxias do Sul, Caxias do Sul, RS, Brazil, from August 2017 to November 2019.

\subsection{Breeding of $T$. vaporariorum individuals}

A population of T. vaporariorum was collected from tomato plants (Solanum lycopersicum) in Santa Lúcia do Piaí (geographical coordinates: $29^{\circ} 12^{\prime} 54.9^{\prime \prime} \mathrm{S} ; 50^{\circ} 59^{\prime 2} 25^{\prime \prime} \mathrm{W}$ ), district of the municipality of Caxias do Sul, RS, Brazil. The colony was kept in bean plants (Phaseolus vulgaris L.), in transparent acrylic boxes inside a greenhouse in the Institute of Biotechnology of UCS.

The $T$. vaporariorum individuals were identified, relative to the biotype, by PCR (polymerase chain reaction) of the mtCOI region and posterior RFLP (Restriction Fragment Length Polymorphism); all carried out in the Universidade Estadual Paulista (UNESP).

\subsection{Plant material for essential oil extraction}

The plant material of Cinnamomum camphora var. linaloolifera was collected in the Institute of Biotechnology of UCS (geographical coordinates: $29^{\circ} 09^{\prime} 47.8^{\prime \prime S ~} 51^{\circ} 08^{\prime} 37.4^{\prime \prime}$ ). After the collection, the material underwent a visual inspection with the remotion of inorganics and decaying plant material. The leaves were separated and dried at room temperature $\left(22-25^{\circ} \mathrm{C}\right)$ for four days in a kiln with forced air circulation.

\subsection{Essential oil extraction and synthetic major compound}

The essential oil was extracted by steam distillation for two hours. The volume of obtained essential oils was measured using a $25 \mathrm{~mL}$ glass graduated cylinder. The essential oil was kept in amber flasks, and $0.5 \mathrm{~mL}$ was sent to chromatographic analysis. The material was stored under refrigeration at $4 \pm 2{ }^{\circ} \mathrm{C}$ until use in the bioassays.

The synthetic compound linalool (CAS 78-70-6, purity of 99.2\%) was purchased from Merck (Germany) and was kept 
under refrigeration at $4 \pm 2{ }^{\circ} \mathrm{C}$ until use in the bioassays.

\subsection{Chromatographic analysis}

The analyses were carried out in the Analytical Central of the Institute of Biotechnology of the UCS, based on the procedures described by Silvestre et al. (2019) and Vicenço et al. (2020). The GC-FID analysis was carried out using a Hewlett Packard 6890 Series gas chromatograph, equipped with an HP-Chemstation data processing unit. An HP-Innowax column (30 m x $320 \mu \mathrm{m}$ i.d.) with $0.50 \mu \mathrm{m}$ film thickness (Hewlett Packard, Palo Alto, USA) was used. Temperature programming was: $40^{\circ} \mathrm{C}$ for $8 \mathrm{~min}$, from $40{ }^{\circ} \mathrm{C}$ to $180{ }^{\circ} \mathrm{C}$ at $3{ }^{\circ} \mathrm{C} \cdot \mathrm{min}^{-1}$, from 180 to $230{ }^{\circ} \mathrm{C}$ at $20{ }^{\circ} \mathrm{C} \cdot \mathrm{min}^{-1}, 230{ }^{\circ} \mathrm{C}$ for $10 \mathrm{~min}$; injector temperature of $250{ }^{\circ} \mathrm{C}$; split ratio 1:50, FID detector at $250{ }^{\circ} \mathrm{C}$; hydrogen as carrier gas at $34 \mathrm{kPa}$, injected volume of $1 \mu \mathrm{L}$, diluted in hexane $(1: 10)$.

The GC/MS analysis was carried out using a gas chromatograph, coupled with an HP 6890/MSD5973 mass spectrometer, equipped with an HP-Chemstation and the Wiley 275 spectra library. An HP-Innowax fused silica capillary column (30 m x $320 \mu \mathrm{m}$ i.d.) with $0.50 \mu \mathrm{m}$ film thickness was used. The temperature program used was the same as GC-FID; interface at $280{ }^{\circ} \mathrm{C}$; split ratio 1:100; helium as carrier gas at $56 \mathrm{kPa}$; flow ratio of $1.0 \mathrm{~mL} \cdot \mathrm{min}^{-1}$; ionization energy of $70 \mathrm{eV}$; injected volume of $1 \mu \mathrm{L}$ diluted in hexane (1:10).

The essential oils components were identified by comparison between the obtained spectra and the ones from the Wiley library (GC/MS) and by comparison of the calculated linear retention indexes (LRI's) and their literature references. The LRI values were calculated using the Van den Dool and Kratz equation and a C8-C30 alkane series solution as standard.

\subsection{Bioassays}

Tests were performed with eggs, nymphs, and adult individuals of $T$. vaporariorum had an experimental design completely randomized. All tests were carried out in an air-conditioned room at $25 \pm 2{ }^{\circ} \mathrm{C}, 50 \pm 5 \% \mathrm{RH}$, and a photoperiod of 14:10 h (light:dark).

For the three stages of $T$. vaporariorum, the treatments were the concentration of essential oil and negative and positive controls. Five concentrations of $C$. camphora essential oil were tested: $0.1,0.5,1.0,1.5$, and $2.0 \% \mathrm{v} / \mathrm{v}$. Also, treatments with the major compound were carried out with nymphs. The same concentrations were used but adjusted to the major compound's content in the essential oil, according to Equation 1.

$$
\mathrm{C}=\mathrm{D} \times \frac{\mathrm{T}}{100}
$$

Being ' $\mathrm{C}$ ' the adjusted concentration, ' $\mathrm{D}$ ' the theoretical dose, and ' $\mathrm{T}$ ' the major compound's content in the essential oil.

All treatments (essential oil and major compound) were emulsified using Tween- $80^{\circledR}(0.5 \% \mathrm{v} / \mathrm{v})$. The recommended pesticides for the control of the T. vaporariorum were used as positive controls. For the adult phase, it was used pymetrozine in the recommended dose of $0.04 \mathrm{wt} . \%$ (Chess ${ }^{\circledast}$, Syngenta), and for the juvenile phase (eggs and nymphs) it was used spiromesifen in the recommended dose of $0.05 \% \mathrm{v} / \mathrm{v}$. (Oberon ${ }^{\circledR}$, Bayer S.A.). Two treatments were used as negative controls: water and Tween $-80^{\circledR} 0.5 \% \mathrm{v} / \mathrm{v}$.

For the tests with the eggs of T. vaporariorum, tomato plants (S. lycopersicum cv. Micro-Tom) with 30 days old underwent visual inspection to exclude plants with any sign of disease or infestation. The selected plants had their leaves removed, except for one leaf. After, 20 adult individuals, not sexed, were transferred from the colony using a manual aspirator. The plants were covered using a voile fabric to avoid insect escape, and they were kept ovipositing for $48 \mathrm{~h}$. After this period, 
the adults were removed, and the leaves with the eggs were treated in the abaxial direction with the essential oil/major compound solutions using a manual sprayer. The treated plants were kept in an air-conditioned room as previously described and the mortality/toxicity evaluations were carried out after eight days. It was counted the number of individuals that reached the first nymphal stage. It was used five replicates for each treatment, being each replicate composed of a plant.

For the tests with the nymphs of $T$. vaporariorum, 20 adult individuals were transferred using a manual aspirator to tomato plants (S. lycopersicum cv. Micro-Tom) with 30 days old. The plants were covered using a voile fabric to avoid insect escape, and they were kept ovipositing for $48 \mathrm{~h}$. After this period, the adults were removed, and the plants were kept in an airconditioned room as previously described. When the nymphs reached the second nymphal stage (which was observed using a magnifier), the treatments were sprayed in the abaxial direction of the leaves using a hand sprayer. The plants were kept in an air-conditioned room, and the evaluation of the mortality/toxicity was carried out after eight days by counting the number of nymphs that reached the fourth nymphal stage and the dead ones. It was used five replicates for each treatment, being each replicate composed of a plant.

For the test with the adult individuals of T. vaporariorum, it was used the methodology described by Müller et al. (2018). Leaves of tomato plant (S. lycopersicum cv. Micro-Tom) with 30 days old were cut and washed with tap water. After, both leaves sides were sprayed with $1 \mathrm{~mL}$ of treatments and kept 30 min away from sunlight to dry on an absorbent paper. Each leaf was put in glass flasks $(7 \mathrm{~cm}$ of diameter and $9 \mathrm{~cm}$ of height) with moistened floral foam. Each flask was infested with five adult individuals of $T$. vaporariorum with the age of 5-7 days by using a manual aspirator. The flasks were closed using black TNT fabric and kept in an air-conditioned room. The mortality percentage of the individuals was evaluated in 24, 48, and $72 \mathrm{~h}$ after infestation. It was used five replicates for each treatment and five individuals for each replicate, totaling 25 individuals for each treatment.

\subsection{Statistical analysis}

Data normality was evaluated using the Kolmogorov-Smirnov test. The parametric data were analyzed by analysis of variance (ANOVA), followed by least significant difference (LSD) test at a 5\% significance level ( $\mathrm{p}<0.05$ ). The Spearman correlation coefficient was also evaluated at a 5\% significance level, aiming to verify possible relationships between mortality data and the concentrations of essential oil/major compound. The data that presented significant correlations were used to generate polynomial regressions to observe the data behavior. The statistical analyses were carried out using the Statistical Package for the Social Sciences software (SPSS for Windows 17.0) (Green \& Salkind, 2005).

\section{Results}

\subsection{Essential oil composition and yield}

The essential oil obtained from the dried leaves of C. camphora has had a yield of $1.60 \% \mathrm{v} / \mathrm{w}$. Sixteen compounds were identified in the essential oil, being linalool the major compound, with $92.34 \mathrm{wt} . \%$ (Table 1). Relative to chemical classes, oxygenated monoterpenes composed most of the essential oil (94.61 wt.\%), followed by small amounts of sesquiterpenes (2.96 wt.\%) and monoterpenes (1.16 wt.\%). 
Table 1. Chromatographic analysis (GC-FID and GC/MS) of Cinnamomum camphora var. linaloolifera essential oil, obtained by steam distillation.

\begin{tabular}{|c|c|c|c|}
\hline Compound & IRL Calc. & IRL Lit. & Content (wt.\%) \\
\hline$\beta$-pinene & 1107 & 1108 & 0.11 \\
\hline Myrcene & 1169 & 1167 & 0.16 \\
\hline$\gamma$-terpinene & 1241 & 1240 & 0.21 \\
\hline o-cymene & 1258 & 1254 & 0.68 \\
\hline cis-linalool oxide & 1444 & 1441 & 0.08 \\
\hline 1-octen-3-ol & 1456 & 1460 & 0.21 \\
\hline Camphor & 1528 & 1531 & 0.42 \\
\hline Linalool & 1555 & 1551 & 92.34 \\
\hline$\beta$-caryophyllene & 1611 & 1610 & 1.84 \\
\hline terpinen-4-ol & 1616 & 1612 & 0.82 \\
\hline$\gamma$-elemene & 1645 & 1644 & 0.11 \\
\hline germacrene-D & 1724 & 1726 & 1.01 \\
\hline cuminal & 1798 & 1794 & 0.07 \\
\hline E,Z-2.6-dimethyl-3.5.7-octatriene-2-ol & 1812 & 1815 & 0.26 \\
\hline E,E-2.6-dimethyl-3.5.7-octatriene-2-ol & 1829 & 1830 & 0.43 \\
\hline$\rho$-cymen-8-ol & 1848 & 1850 & 0.19 \\
\hline \multicolumn{3}{|c|}{ Hydrocarbon monoterpenes } & 1.16 \\
\hline \multicolumn{3}{|c|}{ Oxygenated monoterpenes } & 94.61 \\
\hline \multicolumn{3}{|c|}{ Hydrocarbon sesquiterpenes } & 2.96 \\
\hline \multicolumn{3}{|c|}{ Others } & 0.21 \\
\hline \multicolumn{3}{|c|}{ Not identified } & 1.05 \\
\hline
\end{tabular}

IRL Calc.: calculated linear retention index; IRL Lit.: linear retention index according to literature data (NIST). Source: Authors (2021).

The chromatogram of the FID analysis of the C. camphora essential oil, along with peak identification, is presented in Figure 1.

Figure 1. Chromatogram of the essential oil of Cinnamomum camphora var. linaloolifera.

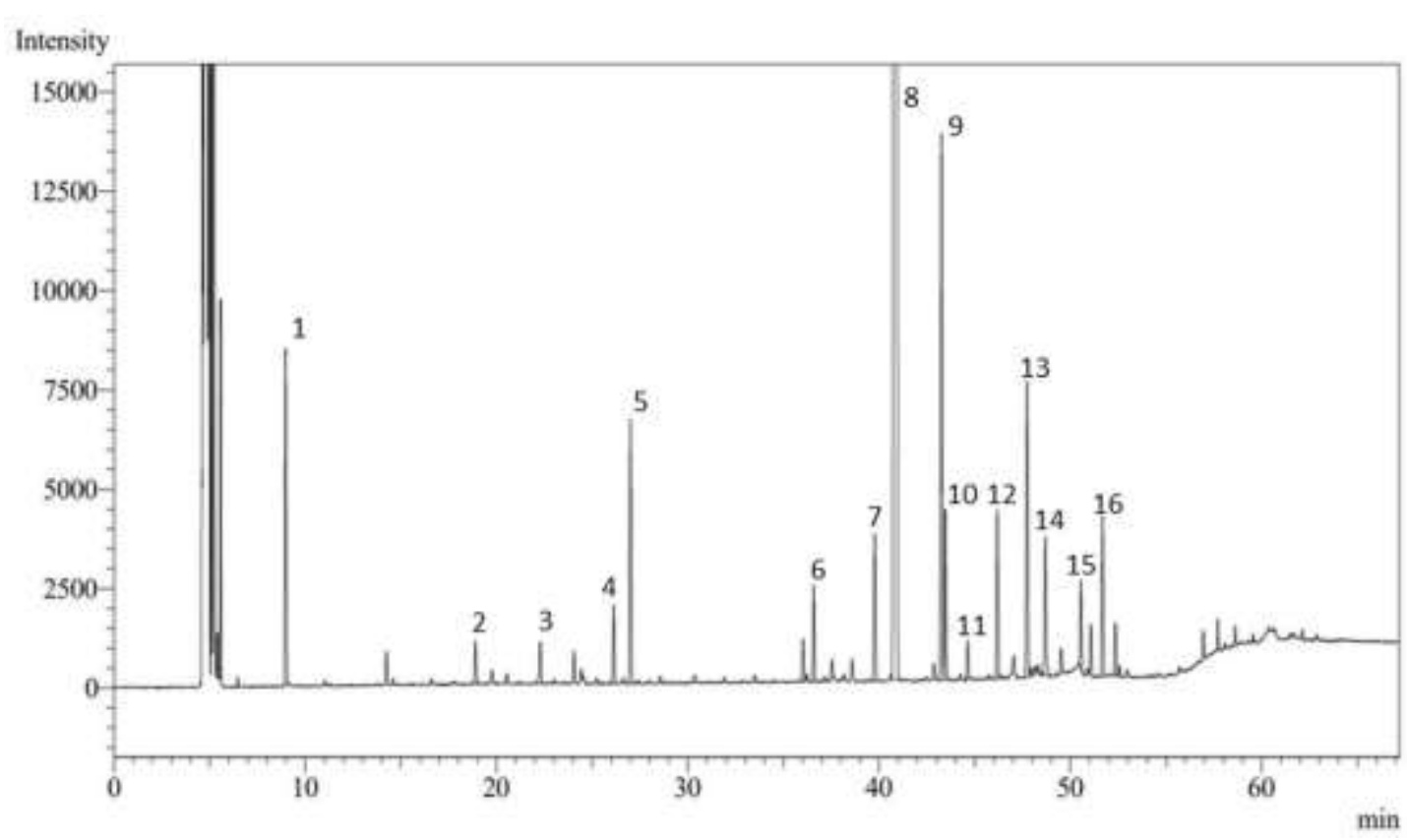

1 - $\beta$-pinene; 2 - myrcene; 3 - $\gamma$-terpinene; 4 - o-cymene; 5 - cis-linalool oxide; 6 - 1 -octen-3-ol; 7 - camphor; 8 - linalol; 9 - $\beta$-caryophyllene; 10 - terpinen-4-ol; 11 - $\gamma$-elemene; 12 - germacrene-D; 13 - cuminal; 14 - E.Z-2,6-dimethyl-3.5.7-octatrien-2-ol; 15 - p-cymen-8-ol; 16 E.E-2,6-dimethyl-3.5.7-octatrien-2-ol.

Source: Authors (2021). 


\subsection{Bioassays}

It was possible to observe a decrease in the number of nymphs that emerged with an increase in essential oil concentration. There was a difference in the mortality of eggs from the concentration of $0.1 \% \mathrm{v} / \mathrm{v}$ of C. camphora essential oil, differing from the negative controls (water and Tween $-80^{\circledR}$ ). However, essential oil treatments presented a lower mortality rate of eggs than the positive control (spiromesifen $0.05 \% \mathrm{v} / \mathrm{v}$ ). The mortality data of eggs and nymphs of $T$. vaporariorum are presented in Table 2.

Table 2. Mortality percentage of eggs and nymphs of T. vaporariorum treated with different concentrations of the essential oil of Cinnamomum camphora var. linaloolifera.

\begin{tabular}{ccc}
\hline Treatments & & Mortality (\%) \\
\cline { 2 - 3 } Water & Eggs & Nymphs \\
\hline Tween-80 0.5\% v/v & $5.49 \mathrm{e}$ & $1.76 \mathrm{e}$ \\
Spiromesifen 0.05\% v/v & $6.22 \mathrm{e}$ & $2.50 \mathrm{e}$ \\
$0.1 \% \mathrm{v} / \mathrm{v}$ & $65.00 \mathrm{a}$ & $98.32 \mathrm{a}$ \\
$0.5 \% \mathrm{v} / \mathrm{v}$ & $23.13 \mathrm{~d}$ & $8.50 \mathrm{e}$ \\
$1.0 \% \mathrm{v} / \mathrm{v}$ & $36.37 \mathrm{c}$ & $29.24 \mathrm{~d}$ \\
$1.5 \% \mathrm{v} / \mathrm{v}$ & $45.55 \mathrm{bc}$ & $78.00 \mathrm{c}$ \\
$2.0 \% \mathrm{v} / \mathrm{v}$ & $30.91 \mathrm{~b}$ & $83.44 \mathrm{bc}$ \\
LSD $(5 \%)$ & $49.37 \mathrm{~b}$ & $88.54 \mathrm{ab}$ \\
F-value & 10.462 & 10.534 \\
p-value & 34.80 & 132.97 \\
\hline
\end{tabular}

Means followed by the same letter in column do not differ statistically by least significant difference (LSD) test at $5 \%$ probability. Source: Authors (2021).

The number of eggs that have not hatched has not differed statistically in the essential oil concentrations of 1.0, 1.5, and $2.0 \% \mathrm{v} / \mathrm{v}$, whose mortality varied between 30.9 and $49.4 \%$. The essential oil concentration of $2.0 \% \mathrm{v} / \mathrm{v}$ had a poorer performance than the positive control (spiromesifen $0.05 \% \mathrm{v} / \mathrm{v}$ ).

For the nymphs (Table 2), it was possible to observe that the concentrations of 1.5 and $2.0 \% \mathrm{v} / \mathrm{v}$ have not differed statistically; there was no difference of the concentration of $2.0 \% \mathrm{v} / \mathrm{v}$ relative to the chemical control $(88.5$ and $98.3 \%$ of individuals mortality, respectively). Also, the concentration of $1.5 \% \mathrm{v} / \mathrm{v}$ has not differed from the concentration of $1.0 \% \mathrm{v} / \mathrm{v}$, causing nymph mortalities of 78.0 and $83.4 \%$, respectively. The essential oil concentration of $0.1 \% \mathrm{v} / \mathrm{v}$ has not differed from the two negative controls (water and Tween- $80^{\circledR}$ ).

The Spearman correlation coefficient between the essential oil concentration of the eggs and nymphs' mortality were 0.7854 and 0.8991 , respectively; both were significant at a $5 \%$ probability. Figure 2 presents the regression graphs between the essential oil concentration and the egg and nymph mortality of de T. vaporariorum. 
Figure 2. Regression graphs of the mortality of eggs (a) and nymphs (b) of $T$. vaporariorum as a function of $C$. camphora essential oil concentration.
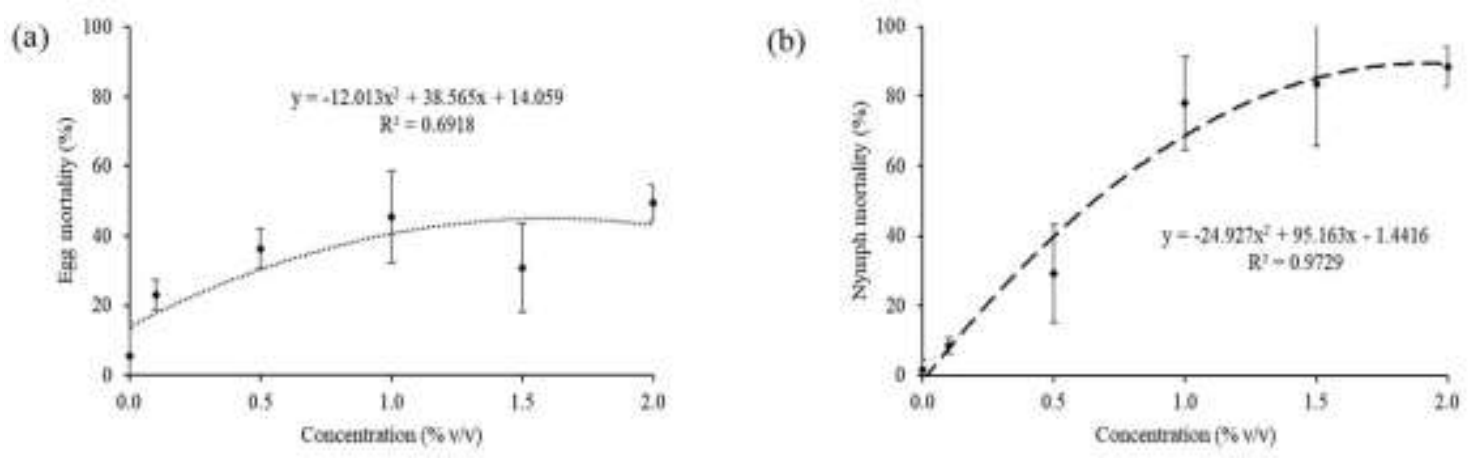

Source: Authors (2021).

It was observed that the mortality of eggs and nymphs followed a quadratic pattern relative to the dose of essential oil, with determination coefficients $\left(\mathrm{R}^{2}\right)$ of 0.6918 for eggs and 0.9729 for nymphs. It is important to note the difference between the egg and nymph mortalities (60 and $90 \%$ for essential oil concentration of $2.0 \% \mathrm{v} / \mathrm{v}$ ), although the regression's overall aspect was similar for both bioassays.

The evaluation of the adult individuals of T. vaporariorum (Table 3) showed a small increase in mortality (12.0\%) at the concentration of $2.0 \% \mathrm{v} / \mathrm{v}$ in the first $24 \mathrm{~h}$, being the only treatment that differed from the others. The mortality percentage after $48 \mathrm{~h}$ increased to $40 \%$ at the same concentration. This value has not increased, remaining unchanged after $72 \mathrm{~h}$. Noteworthy, insecticide pymetrozine caused insect mortality only after $48 \mathrm{~h}(64.0 \%)$; this percentage increased to $72.0 \%$ after $72 \mathrm{~h}$.

Table 3. Mortality percentage of adult individuals of T. vaporariorum treated with different concentrations of Cinnamomum camphora var. linaloolifera essential oil, in different evaluation times.

\begin{tabular}{cccc}
\hline Treatments & \multicolumn{3}{c}{ Mortality $(\%)$} \\
\cline { 2 - 4 } Water & $24 \mathrm{~h}$ & $48 \mathrm{~h}$ & $0.00 \mathrm{c}$ \\
Tween-80 0.5\% v/v & $0.00 \mathrm{a}$ & $0.00 \mathrm{~d}$ & $0.00 \mathrm{c}$ \\
Pymetrozine $0.04 \% \mathrm{~m} / \mathrm{v}$ & $0.00 \mathrm{a}$ & $0.00 \mathrm{~d}$ & $72.00 \mathrm{a}$ \\
$0.1 \% \mathrm{v} / \mathrm{v}$ & $0.00 \mathrm{a}$ & $64.00 \mathrm{a}$ & $0.00 \mathrm{c}$ \\
$0.5 \% \mathrm{v} / \mathrm{v}$ & $0.00 \mathrm{a}$ & $0.00 \mathrm{~d}$ & $0.00 \mathrm{c}$ \\
$1.0 \% \mathrm{v} / \mathrm{v}$ & $0.00 \mathrm{a}$ & $0.00 \mathrm{~d}$ & $0.00 \mathrm{c}$ \\
$1.5 \% \mathrm{v} / \mathrm{v}$ & $0.00 \mathrm{a}$ & $0.00 \mathrm{~d}$ & $12.00 \mathrm{c}$ \\
$2.0 \% \mathrm{v} / \mathrm{v}$ & $0.00 \mathrm{a}$ & $12.00 \mathrm{c}$ & $40.00 \mathrm{~b}$ \\
\hline LSD $(5 \%)$ & $12.00 \mathrm{~b}$ & $40.00 \mathrm{~b}$ & 13.201 \\
F-value & 8.148 & 11.157 & 34.05 \\
p-value & 2.25 & 39.60 & $<0.0001$ \\
\hline
\end{tabular}

Means followed by the same letter in column do not differ statistically by least significant difference (LSD) test at $5 \%$ probability. Source: Authors (2021).

The determination of the Spearman correlation coefficient indicated the existence of three significant correlations between the mortalities of adult individuals at 24 (0.4167), 48, and $72 \mathrm{~h}(0.7553$ in both). Figure 3 presents the regression data of the adult mortality relative to the evaluation times and the concentration of $C$. camphora essential oil. 
Figure 3. Regression graphs of the mortality of adult individuals of T. vaporariorum after 24 (dashed line) and 48/72 h (dotted line) as a function of the concentration of C. camphora essential oil.

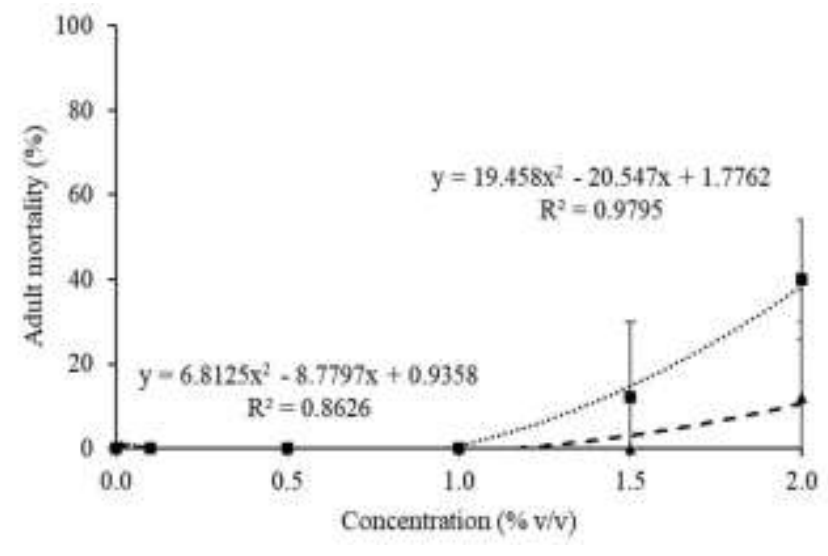

Source: Authors (2021).

The bioassay that compared the essential oil of $C$. camphora and linalool, its major compound, (Table 4), showed that linalool caused higher mortality percentages of nymphs at the concentrations of 0.5 and $1.0 \% \mathrm{v} / \mathrm{v}$ when compared to the essential oil.

Table 4. T. vaporariorum nymph mortality percentage treated with Cinnamomum camphora var. linaloolifera essential oil and linalool, its major compound.

\begin{tabular}{|c|c|c|}
\hline Treatment & C. camphora & Linalool \\
\hline Water & $1.76 \mathrm{Ad}$ & $1.76 \mathrm{Ac}$ \\
\hline Tween-80 0.5\% v/v & $2.50 \mathrm{Ad}$ & $2.50 \mathrm{Ac}$ \\
\hline Spiromesifen $0.05 \% \mathrm{v} / \mathrm{v}$ & $98.32 \mathrm{Aa}$ & $98.32 \mathrm{Aa}$ \\
\hline $0.5 \% \mathrm{v} / \mathrm{v}^{*}$ & $29.24 \mathrm{Bc}$ & $55.56 \mathrm{Ab}$ \\
\hline $1.0 \% \mathrm{v} / \mathrm{v}^{*}$ & $65.65 \mathrm{Bb}$ & $78.00 \mathrm{Ab}$ \\
\hline $1.5 \% \mathrm{v} / \mathrm{v}^{*}$ & $83.44 \mathrm{Ab}$ & $90.76 \mathrm{Aa}$ \\
\hline $2.0 \% \mathrm{v} / \mathrm{v} *$ & $88.54 \mathrm{Aab}$ & $87.70 \mathrm{Aa}$ \\
\hline Factor & F-value & p-value \\
\hline Essential oil kind & 1.86 & 0.178 \\
\hline Concentration & 208.61 & $<0.0001$ \\
\hline Interaction between factors & 4.37 & 0.0011 \\
\hline $\operatorname{LSD}(5 \%)$ & \multirow{2}{*}{\multicolumn{2}{|c|}{$\begin{array}{c}11.341 \\
1598\end{array}$}} \\
\hline Coefficient of variation (\%) & & \\
\hline
\end{tabular}

Means followed by the same letter, uppercase in row (OE kind) and lowercase in column (concentration) do not differ statistically by the least significant difference (LSD) test at 5\%. * The concentration of the major compound was adjusted according to its content in the essential oil.

Source: Authors (2021).

However, at higher concentrations (from $1.5 \% \mathrm{v} / \mathrm{v}$ on), no statistical difference was observed between the two treatments. Moreover, essential oil from $1.5 \% \mathrm{v} / \mathrm{v}$ on, linalool and chemical control (spiromesifen) have had a similar performance, in which the mortality percentages of $T$. vaporariorum nymphs were above $90 \%$ for both treatments.

The test also indicated that linalool was the primary insecticidal agent in the essential oil of C. camphora var. linaloolifera. As the concentration of essential oil increased, the mortality percentage increased considerably; from $1.5 \% \mathrm{v} / \mathrm{v}$ on, the essential oil's toxic effect has not differed from the one of linalool. These results may indicate that the major compound (linalool) concentration in the essential oil was sufficient to suppress possible minor compounds' antagonistic effects.

The Spearman correlation coefficient indicated a significant correlation between nymph mortality and linalool concentration (0.8443), beyond the already established correlation with $C$. camphora essential oil (0.8891). Figure 4 presents the 
regression graphs of $T$. vaporariorum nymph mortality relative to both linalool and $C$. camphora essential oil concentrations.

Figure 4. Regression graphs of T. vaporariorum nymph mortality as a function of the concentration of $C$. camphora essential oil (dashed line) and linalool (dotted line).

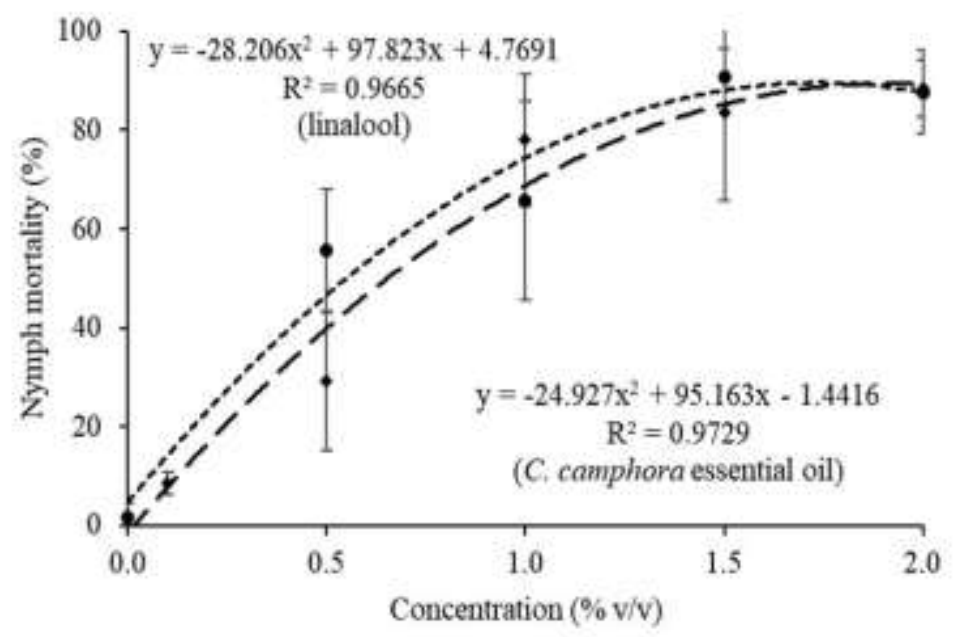

Source: Authors (2021).

Evaluating the graph shows that $T$. vaporariorum nymphs' mortality data exposed to both the essential oil and linalool fitted similarly, with a quadratic fit. It indicates both treatments presented the same toxic effect on nymphs of this pest, with mortalities ranging from 85 to $90 \%$ for a concentration of $2.0 \% \mathrm{v} / \mathrm{v}$.

\section{Discussion}

\subsection{Essential oil yield and composition}

Relative to C. camphora essential oil, other authors reported similar results, which also characterized linalool as the major compound of this essential oil in contents ranging from 84 to 95 wt.\% (Cansian et al., 2010, 2015; Nenaah \& Ibrahim, 2011; Tomazoni et al., 2017).

The compounds found in the essential oil are classified into two main chemical groups, varying according to the metabolic pathway from which they originated: terpenes (mono-, sesqui-, and diterpenes) and, in lower contents, phenylpropanoids (Regnault-Roger et al., 2012). In plants, monoterpenes act as defense agents against pathogens due to allelochemical and repellent activities, among other functions (Chand et al., 2017).

The physiological expression of secondary metabolism of plants may differ due to the stage of development (Hansted et al., 1994; Raguso \& Pichersky, 1999). The proportion of monoterpenes, for example, depends on circadian rhythm and varies according to the plant stage (Clark \& Menary, 1981). Some plant species also have different chemotypes, i.e., they are botanically and genetically identical. However, they differ in the level of gene expression, which is linked to the activation of several metabolic pathways due to specific alleles' presence or activation (Regnault-Roger et al., 2012).

Essential oil composition also may be changed during the extraction process. Water kind and quality, acidity, and extraction temperature may cause oxidation and hydrolysis of terpenes. The storage conditions are also quite crucial since the degradation possibilities are many. These essential oil changes occur mostly by polymerization and oxidation reactions (Simões et al., 2017). 


\subsection{Insecticidal activity of $C$. camphora essential oil on $T$. vaporariorum}

Literature is scarce about the effect of the essential oil of C. camphora in the juvenile phase (eggs and nymphs) of $T$. vaporariorum, neither other species, having only studies relative to the adult phase. The essential oil of $C$. camphora has had toxicity on Sitophilus zeamais, causing 100\% mortality at the concentration of $0.114 \% \mathrm{v} / \mathrm{v}$ (Cansian et al., 2015).

The behavior observed in the present work may indicate that, at higher concentrations ( 1.5 and $2.0 \% \mathrm{v} / \mathrm{v})$, the effect of the essential oil on egg and nymph mortality becomes constant, not increasing in higher concentrations. Pereira et al. (2018), using essential oil from the fruits of Zanthoxylum riedelianum to control second-instar nymphs of Bemisia tabaci, reported a loglogistic fit of the data in function of the concentration, with mortalities in the range of 50-80\%.

Essential oils contain several compounds that can exert repellent and insecticidal mechanisms. Many studies have demonstrated that these compounds have biological activity and can cause adverse effects on several pests (Dhifi et al., 2016). The toxicity of essential oil on insects, nematodes, fungi, bacteria, and other organisms may be attributed to the terpenic compounds present in these oils (Regnault-Roger et al., 2012; Pavela \& Benelli, 2016). The quick action of these natural products against insects may be indicative of neurotoxic action. There is evidence of interference of terpenes with the neuromodulator octopamine or GABA-modulated calcium channels (Priestley et al., 2003; Isman, 2006). They can also affect acetylcholinesterase, octopamine, sodium channels, among other mechanisms (Huignard et al., 2008; Regnault-Roger et al., 2012; Campos et al., 2018). However, the essential oils' action capacity is poorly understood, since the toxic effect may differ according to the quality and quantity of the compounds present in the essential oil (Campos et al., 2018).

Considering the crescent necessity of the development and use of more environmentally friendly molecules, the $C$. camphora essential oil presents itself as a feasible alternative due to the relatively high oil yield (about $2.0 \% \mathrm{v} / \mathrm{w}$ ) and the high content of linalool (the linaloolifera variety). The use of natural molecules over synthetic ones is also interesting due to the biodegradability, low presence of residues, and a slower resistance development by the target pests (Cansian et al., 2015; Pavella \& Benelli, 2016; Campos et al., 2018).

According to the EPA (Environmental Protection Agency, 2019), to register a pesticide, the substance must cause at least $90 \%$ of the target individuals' mortality. In the present study, the chemical pesticides caused a $T$. vaporariorum egg mortality of $65 \%$ and an adult mortality of $72 \%$ after $72 \mathrm{~h}$ of evaluation, indicating that this pest may have developed some resistance mechanism against these pesticides (spiromesifen and pymetrozine). Zhou et al. (2019) reported a linear increase in the mortality of Aphis pomi with time when exposed to small concentrations of Dracocephalum integrifolium essential oil; however, as the essential oil concentration increased, the effect was more pronounced, reaching higher mortalities at the same time.

Taking into account the IPM method, a comprehensive control using several mechanisms (natural predators, natural and synthetic chemicals, management procedures) also helps in hindering resistance development and increasing the overall control efficiency without excessive use of any of the control methods (Nerio et al., 2012; Regnault-Roger et al., 2012). In this sense, the leaf essential oil of $C$. camphora as a control tool in the integrated management of $T$. vaporariorum may be a valuable and important tool in promoting more eco-friendly and efficient management of the cultures affected by this insect.

\section{Conclusion}

The chemical analysis of the essential oil of $C$. camphora showed linalool as the major compound, with 92.34 wt.\%. According to the results, the C. camphora essential oil presented a moderate activity on eggs and adult individuals of $T$. vaporariorum and was successful in controlling the nymphs of this pest. Thus, this essential oil may be an effective alternative and an option in the management of this insect, especially in light of the MIP procedures. 


\section{References}

Barbosa, F. R., Siqueira, K. M. M., Souza, E. A., Moreira, W. A., Haji, F. N. P. \& Alencar, J. A. (2002). Efeito do controle químico da mosca-branca na incidência do vírus-do-mosaico-dourado e na produtividade do feijoeiro. Pesquisa Agropecuária Brasileira, 37, 879-883.

Center for Agriculture and Biosciences International (CABI). (2017). Invasive Species Compendium: Trialeurodes vaporariorum (greenhouse whitefly). http://www.cabi.org/isc/datasheet/54660.

Campos, E. V. R., Proença, P. L. F., Oliveira, J. L., Bakshi, M., Abhilash, P. C. \& Fraceto, L. F. (2018). Use of botanical insecticides for sustainable agriculture: Future perspectives. Ecological Indicators, 105, 483-495. https://doi.org/10.1016/j.ecolind.2018.04.038.

Cansian, R. L., Mossi, A. J., Oliveira, D., Toniazzo, G., Treichel, H., Paroul, N., Astolfi, V. \& Serafini, L. A. (2010). Atividade antimicrobiana e antioxidante do óleo essencial de ho-sho (Cinnamomum camphora Ness e Eberm Var. Linaloolifera fujita). Ciência \& Tecnologia de Alimentos, 30, 378-384.

Cansian, R. L., Astolfi, V., Cardoso, R. I., Paroul, N., Roman, S. S., Mielniczki-Pereira, A. A., Pauletti, G. F. \& Mossi, A. J. (2015). Insecticidal and repellent activity of the essential oil of Cinnamomum camphora var. linaloolifera Y. Fujita (Ho-Sho) and Cinnamomum camphora (L.) J Presl. var. hosyo (Hon-Sho) on Sitophilus zeamais Mots. (Coleoptera, Curculionedae). Revista Brasileira de Plantas Medicinais, 17, 769-773.

Capinera, J. L. (2008). Greenhouse Whitefly, Trialeurodes vaporariorum (Westwood) (Hemiptera: Aleyrodidae). In Capinera, J. R. (Ed.). Encyclopedia of Entomology. Springer Netherlands.

Chand, R. R., Jokhan, A. D. \& Gopalan, R. D. (2017). A mini-review of essential oils in the South Pacific and their insecticidal properties. Advances in Horticultural Science, 31, 295-310. https://10.13128/ahs-20833.

Clark, R. J. \& Menary, R. C. (1981). Variations in composition of peppermint oil in relation to production areas. Economic Botany, 35, 59-69. https://doi.org/10.1007/BF02859215.

Dhifi, W., Bellili, S., Jazi, S., Bahloul, N. \& Mnif, W. (2016). Essential Oils' Chemical Characterization and Investigation of Some Biological Activities: A Critical Review. Medicines, 3, 25. 10.3390/medicines3040025.

Environmental Protection Agency (EPA). 2019. Guidance on Efficacy Testing for Pesticides Targeting Certain Invertebrate Pests. https://www.epa.gov/pesticide-registration/guidance-efficacy-testing-pesticides-targeting-certain-invertebrate-pests.

Erdogan, C., Velioglu, A. S., Gurkan, M. O., Denholm, I. \& Moores, G. D. (2012). Chlorpyrifos ethyl-oxon sensitive and insensitive acetylcholinesterase variants of greenhouse whitefly Trialeurodes vaporariorum (Westwood.) (Hemiptera: Aleyrodidae) from Turkey. Pest Biochemistry \& Physiology, 104, 273-276. 10.1016/j.pestbp.2012.09.009

Gilles, M., Zhao, J., Na, M. \& Agboola, S. (2010). Chemical composition and antimicrobial properties of essential oils of three Australian Eucalyptus species. Food Chemistry, 119, 731-737.

Green, S. B. \& Salkind, N. J. (2005). Using SPSS for Windows and Macintosh: Analyzing and understanding data.

Hansted, L., Jakobsen, H. B. \& Olsen, C. E. (1994). Influence of temperature on the rhythmic emission of volatiles from Ribes nigrum flowers in situ. Plant, Cell \& Environment, 17, 1069-1072. https://doi.org/10.1111/j.1365-3040.1994.tb02030.x.

Henneberry, T. J., Jech, L., Hendrix, D. L. \& Steele, T. (1999). Bemisia argentifolii (Homoptera: Aleyrodidae). Factors affecting adult and nymph honeydew production. Southwestern Entomology, 24, 207-231.

Huignard, J., Lapied, B., Dugravot, S., Magnin-Robert, M. \& Ketoh, G. K. (2008). Modes d'action neurotoxiques des derives soufrés et de certaines huiles essentielles et risques lies à leur utilization. In: Regnault-Roger, C., Philogène, B. J. R. \& Vincent, C. (Eds.). Biopesticides d’Origine Végétale, (2nd ed.), Paris: Lavoisier Tech \& Doc. p. 219-231.

Isman, M.B. (2006). Botanical insecticides, deterrents, and repellents in modern agriculture and an increasingly regulated world. Annual Reviews in Entomology, 51, 45-66. https://doi.org/10.1146/annurev.ento.51.110104.151146.

Koul, O., Walia, S. \& Dhaliwal, G. S. (2008). Essential Oils as Green Pesticides: Potential and Constraints. Biopesticides International, 4, 63-84.

Liu, C. H., Mishra, A. K., Tan, R. X., Tang, C., Yang, H. \& Shen, Y. F. (2006). Repellent and insecticidal activities of essential oils from Artemisia princeps and Cinnamomum camphora and their effect on seed germination of wheat and broad bean. Bioresource Technology, 97, 1969-1973.

Lourenção, A. L., Alves, A. C., Fugi, C. G. Q. \& Matos, E. S. (2008). Outbreaks of Trialeurodes vaporariorum (West.) (Hemiptera: Aleyrodidae) Under Field Conditions in the State of São Paulo, Brazil. Neotropical Entomology, 37, 89-91.

Morais, L. A. S. (2009). Influência dos fatores abióticos na composição química dos óleos essenciais. Horticultura Brasileira, 27 , S4050-S4063.

Michereff Filho, M. M. \& Inoue-Nagata, A. K. (2015). Guia para o reconhecimento e manejo da mosca-branca, da Geminivirose e da Crinivirose na cultura do tomateiro. Brasília: Embrapa Hortaliças.

Müller, C., Alvarez, D. L., Miraldo, L. L., Mocheti, M., Santos, L. M., Santos, A. C. \& Bueno, R. C. O. F. (2018). Comparison of Insecticide Bioassay Methods in Sweet Potato Whitefly Adults. Arthropod Management Tests, 43, 1-2. https://doi.org/10.1093/amt/tsy108

Nenaah, G. E. \& Ibrahim, S. I. A. (2011). Chemical composition and the insecticidal activity of certain plants applied as powders and essential oils against two stored-products coleopteran beetles. Journal of Pest Science, 84, 393-402.

Nerio, L. S., Olivero-Verbel, J. \& Stashenko, E. (2010). Repellent Activity of Essential Oils: A Review. Bioresource Technology, 101, $372-378$. 
Ovčarenko, I., Lindström, L., Saikkonen, K. \& Vänninen, I. (2014). Variation in mortality among populations is higher for pymetrozine than for imidacloprid and spiromesifen in Trialeurodes vaporariorum in greenhouses in Finland. Pest Management Science, 70, 1524-1530.

Pandey, A. K., Singh, P. \& Tripathi, N. N. (2014). Chemistry and bioactivities of essential oils of some Ocimum species: an overview. Asian-Pacific Journal of Tropical Biomedicine, 4, 682-694. https://doi.org/10.12980/APJTB.4.2014C77

Pavella, R. \& Benelli, G. (2016). Essential Oils as Ecofriendly Biopesticides? Challenges and Constraints. Trends in Plant Science, 12, $1000-1006$.

Pereira, K. C., Quintela, E. D., Silva, D. J., Nascimento, V. A., Rocha, D. V. M., Silva, J. F. A., Forim, M. R., Silva, F. G. \& Cazal, C. M. (2018). Characterization of Nanospheres Containing Zanthoxylum riedelianum Fruit Essential Oil and Their Insecticidal and Deterrent Activities against Bemisia tabaci (Hemiptera: Aleyrodidae). Molecules, 23, 2052. 10.3390/molecules23082052.

Perring, T. M., Stansly, P. A., Liu, T. X., Smith, H. A. \& Andreason, S. A. (2018). Whiteflies: Biology, Ecology, and Management. In: Wakil, W., Brust. G. E. \& Perring, T. M. (Eds.). Sustainable Management of Arthropod Pests of Tomato. London, UK: Elsevier. pp. 73-109.

Priestley, C. M., Williamson, E. M., Wafford, K. A. \& Sattelle, D. B. (2003). Thymol, a constituent of thyme essential oil, is a positive allosteric modulator of human GABA receptors and a homo-oligomeric GABA receptor from Drosophila melanogaster. British Journal of Pharmacology, 140, 1363-1372. https://doi.org/10.1038/sj.bjp.0705542.

Raguso, R. A. \& Pichersky, E. (1999). New perspectives in pollination biology: floral fragrances. A day in the life of a linalool molecule: chemical communication in a plant-pollinator system. Part 1: linalool biosynthesis in flowering plants. Plant Species Biology, 14, 95-120. https://doi.org/10.1046/j.14421984.1999.00014.x

Regnault-Roger, C. \& Hamraoui, A. (1995). Fumigant toxic activity and reproductive inhibition induced by Monoterpenes upon Acanthoscelides obtectus Say (Coleoptera), bruchid of kidney bean (Phaseolus vulgaris). Journal of Stored Products Research, 31, 291-299. 10.1016/0022-474X(95)00025-3.

Regnault-Roger, C., Vincent, C. \& Thor, J. (2012). Essential oils in insect control: low-risk products in a high-stakes world. Annual Reviews in Entomology, 57, 405-424. https://10.1146/annurev-ento-120710-100554.

Sell, C. S. (2006). The Chemistry of Fragrance. From Perfumer to Consumer. (2nd ed.), The Royal Society of Chemistry. 329 p.

Silvestre, W. P., Medeiros, F. R., Agostini, F., Toss, D. \& Pauletti, G. F. (2019). Fractionation of rosemary (Rosmarinus officinalis L.) essential oil using vacuum fractional distillation. Journal of Food Science and Technology, 56, 5422-5434. https://doi.org/10.1007/s13197-019-04013-z.

Simões, C. M. O., Schenkel, E. P., Mello, J. C. P., Mentz, L. A. \& Petrovick, P. R. (2017). Farmacognosia: do produto natural ao Medicamento. (4th ed.), Artmed.

Tambwe, M. M., Mbeyela, E. M., Massinda, B. M., Moore, S. J. \& Maia, M. F. (2014). Experimental hut evaluation of linalool spatial repellent agar gel against Anopheles gambiae sensu stricto mosquitoes in a semi-field system in Bagamoyo, Tanzania. Parasities \& Vectors, 7.

Tomazoni, E. Z., Pauletti, G. F., Ribeiro, R. T. S., Moura, S. \& Schwambach, J. (2017). In vitro and in vivo activity of essential oils extracted from Eucalyptus staigeriana, Eucalyptus globulus and Cinnamomum camphora against Alternaria solani Sorauer causing early blight in tomato. Scientia Horticulturae, 223, 7277.

Vicenço, C. B., Silvestre, W. P., Silva, V. T., Menegol, I. V., Hahn, R. C., Lima, T. S., Agostini, F. \& Pauletti, G. F. (2020). Bioactivity of Schinus molle L. and Schinus terebinthifolia Raddi. Essential Oils on Anticarsia gemmatalis (Hübner 1818). Brazilian Archives of Biology and Technology, 63 , e20200111.

Wang, C. F., Yang, K., Zhang, H. M., Cao, J., Fang, R., Liu, Z. L., Du, S. S., Wang, Y. Y., Deng, Z. W. \& Zhou, L. (2011). Components and insecticidal activity against the maize weevils of Zanthoxylum schinifolium fruits and leaves. Molecules, 16, 3077-3088.

Zapata, N., Vargas, M., Latorre, E., Roudergue, X. \& Ceballos, R. (2016). The essential oil of Laurelia sempervirens is toxic to Trialeurodes vaporariorum and Encarsia formosa. Industrial Crops and Products, 84, 418-422. http://dx.doi.org/10.1016/j.indcrop.2016.02.030

Zhou, S., Wei, C., Zhang, C., Han, C., Kuchkarova, N. \& Shao, H. (2019). Chemical Composition, Phytotoxic, Antimicrobial and Insecticidal Activity of the Essential Oils of Dracocephalum integrifolium. Toxins, 11, 598. 10.3390/toxins11100598. 